\title{
SOCIAL MEDIA AS THE PLATFORM FOR POLITICAL MOBILIZATION: CASE STUDY OF KAZAKHSTAN
}

\author{
Assem Kalkamanova ${ }^{1}$
}

DOI: $10.24989 /$ ocg.338.34

\begin{abstract}
This paper focuses on the role of social media in the rise of the protest movements and political mobilization in Kazakhstan. The country has been seeing an increase in the social networks based civil activists since recently. I argue that the emergence of the Democratic Choice of Kazakhstan that operates only within the realm of social media platforms promoted political activism and civil protests in the country. Most importantly, I argue that in contrast to the conclusions of the Kazakhstani court's decision in March 2018, the movement leader's Facebook blog reveals no violence either towards the government or some specific political elite. Using text mining methods, I analyzed the texts of his Facebook posts from the announcement date in 2017 till the end of 2019: the rhetoric of the position of the Democratic Choice is informational, first, and protest calling, second. Also, the analysis of seven most popular political Youtube bloggers shows that the people's discontent with injustices and undemocratic polity manifested in the poignant interest towards the creator of this system, Mr. Nazarbayev and his closest circle. The SMM software allowed to find out the areas of Kazakhstani politics that are of most interest to the audience of Kazakhstani political activists.
\end{abstract}

\section{Introduction}

No doubt that Kazakhstan has recently joined the group of countries touched by the notion of "the networked social movements" propounded by Castells M. (2015). [2] Since 2013, a lot of Youtube and Facebook blogs started to emerge. Using social media blogs, political activists started to express their grievances and question the legitimacy of the political regime developed since the independence in 1990. Later, in April 2017, with the foundation of the only organized oppositional movement, Democratic Choice of Kazakhstan (DCK), which currently exists only on social media platforms people started to acquire alternative information encouraging each other to take their protests to the streets. No wonder that in March 2018 Kazakhstani court found the movement "extremist".

Although social movements and contentious politics are an integral part of political systems, autocratic regimes are inherently opposed to contentious collective actions because they facilitate the breakdown of such regimes. While, obviously, the goal of such regimes is to maintain power for as long as possible.

This study uses a Social Media Management software to analyze how social media is associated with the mobilization process, protest tactics and oppositional movement. Using SMM software LiveDunes I examined Youtube blogs of seven oppositional channels whose authors' identities are known. I collected data on their video-post statistics for the period 2015-2019 (or since their start).

\footnotetext{
${ }^{1}$ Faculty of Law and Political sciences, University of Szeged, Bocskai Street 10-12, Szeged, Hungary, assemk@irsi.uszeged.hu, a.kalkaman@gmail.com
} 
The Kazakhstani political online sphere exists in the form of personal blogs or accounts on Facebook, Youtube and Instagram. According to the social media statistics by StatCounter.com Pinterest (31.52\%), Facebook (21.22\%), and Youtube (16.13\%) have the largest market share in Kazakhstan. While Vkontakte (Russian based), Instagram, and Twitter also had significant market shares in December 2019. [15] The DCK is represented on three social networks: Facebook, Youtube and Instagram by the accounts of the leader M. Ablyazov and the Channel 16/12.

The history of political mobilization in Kazakhstan can be divided into two periods before and after the foundation date of the social movement Democratic Choice of Kazakhstan was announced on Facebook page by its leader, M. Ablyazov, the dissident living in France (April 2017). [1] By assembling data on all contentious collective actions in the country during the period of five years, 2015-2019, I attempt to analyze how the protest activity has changed since the DCK.

I use text mining in $\mathrm{R}$ based on the textual data from Facebook posts of the leader of the DCK movement, M. Ablyazov, for the period 2017-2019. It allows to conclude on the main claims and grievances highlighted by the opposition. In-depth automated text analytics provided lots of reliable statistics. Most comprehensive was cluster analysis on texts. I argue that the oppositional movement DCK posts on Facebook do not imply any violence or use of illegal criminal methods in their protest rallies. Moreover, their channel bears mostly informational character. My conclusions on the effect of opposition movements working through social media and rendering results in public sphere provide the only positive glimpses for the growth of civil society in authoritarian state.

\section{Defining political mobilization in modern authoritarian regimes}

It is very important to distinguish politics in a non-democratic regime from the politics in a democratic one. Since 2006 democratic recession started to show its signs: number of electoral and liberal democracies started to decline and then halted. $[5,99]$ These trends automatically imply the rise of authoritarianism. In addition, modern non-democratic regimes acquired new features: "illiberal leaders have managed to concentrate power without cutting their countries off from global markets, imposing exotic social philosophies, or resorting to mass murder. Many of these new-style autocrats have come to office in elections and managed to preserve a democratic facade while covertly subverting political institutions." [8, 100] In spite of the democratic façade, political institutions in the hybrid-autocratic regimes not only do not fulfil their functions but also discourage people from the participation in public life and decision making. Charles Tilly referring to the non-democratic regimes claimed that the political participation "consists of voting, party work, holding office and communicating with legislators: people whose problems these procedures won't solve tend to withdraw or to act outside the political system." [16, 3-10] That is why after the major Internet social networks appeared around 2010's (Facebook and Youtube), the political activism in the authoritarian regimes has moved on these platforms. Since the traditional media are usually controlled by the government or political elites, communication and information dissemination are skewed in favor of those controlling them. Thus, social networks as the fastest tool of the information dissemination pose serious threats to the ruling elites in the authoritarian countries by reducing the knowledge gap which made ruling elites seriously concerned with the internet control: "Social media serves as a tactical tool (a means to disseminate information, coordinate action, and publicize the cause) as well as an emotional conduit (a place to develop identity, share emotions, and symbolically construct a sense of togetherness among activists)". [12,2] Due to these factors, social media facilitate the mobilizational processes in society. In non-democratic regimes, they become the only available tool for mobilization. Numerous studies on the Arab spring events confirm these trends. One of the most famous studies on the Egypt Revolution by Tufekci \& Wilson [17,363] based on the comprehensive survey proved 
empirically that Facebook significantly contributed to the increase of participants in Tahrir square uprisings and the likelihood of success of the revolution.

However, there is an alternative pessimistic view: some scholars like Morozov [13] view the internet as a support for the authoritarianism calling it "net delusion" because of the increasing control over the internet and new surveillance technologies.

\section{Political regime of Kazakhstan}

No doubt, since 1991 after the establishment of the independent Republic of Kazakhstan, a political regime with distinct autocratic characteristics developed. The confirmation of the autocratic nature of the country's regime can be found in the reports by international research centers. Freedom House country report concludes that Kazakhstan is "not free" with the score 22 (the range is from 0 as least free to 100 as most free nations). [6] In May 2019 the study of Pew Research based on the data from Polity IV project Kazakhstan was described as an autocracy. [4]

Executive power in Kazakhstan consists of the first president "Leader of the Nation" (also, the lifelong Chairman of the Security Council, Nazarbayev), the president (Tokayev) and the cabinet (government). The first president, Nazarbayev, has been president from 1990 till 2019. In spite of the change of the incumbent last year, legislation and separation of powers is structured in such a way that the first president (which is an official title and status) keeps overwhelming competences in state governance: all major public policy decisions are made by him.

Taking into account the current political institutes, executive-legislative disbalance and other factors, I associate a political regime in Kazakhstan with the sultanistic regime propounded by Linz in his seminal books. [10], [11] Also, Geddes [7] classification with its personalist authoritarian type is adequately applicable to the Kazakhstani regime. Linz actually developed the sultanistic regimes out of the patrimonialism concept elaborated on by Max Weber. [3, 4] It is very interesting to observe how theoretical conclusions realize practically almost 50 years after the first mentioning of sultanistic regimes as separate from the authoritarian and totalitarian regimes.

Strong single party rule of Soviet times transformed into the single person dictatorship of the sultanistic character. The presence of democratic institutions is not uncommon to the sultanistic regimes: elected president, parliament and even multi-party system. As Linz noticed „Sultanistic rulers also often turn to plebiscites to prove their democratic legitimacy; needless to say, they never lose one. Plebiscites are part of the democratic facade that sultanistic rulers like to erect, but they also create the image of a charismatic leader who rules by popular acclamation." $[3,19]$

The main features of the sultanistic regimes are relevant to Kazakhstani system: strong neopatrimonialism, high corruption rates, pronounced personality cult and dynasticism (invention of new titles for the ruler), weak links with civil society, the absence of secure private property rights, arbitrariness in the judiciary system, oppositional activity is concentrated abroad, exile opposition.

Besides the earlier mentioned opposition leader, the leader of the movement DCK, there are several political activists in Ukraine who were previously prosecuted in Kazakhstan and fled to Ukraine. Also, the political system of Kazakhstan as the majority of modern authoritarian regimes is an informational autocracy (term by Guriev and Treisman). [8, 112] The informational autocracies are characterized by the fact that due to the propaganda through the state-controlled media, there is a gap in the political knowledge between the intellectuals with the higher education and the general public. 
$[8,101]$ The highly educated or "informed elite" are more critical to the current political situation than the general public in modern autocracies because of less susceptibility to the propaganda by state-controlled media. $[8,101]$ This is one more factor against political pluralism in such countries.

There are two arguments confirming the absence of political pluralism and the functioning civil society. Firstly, three parties are represented in the parliament. The propresidential party takes 84 seats out of $98(82 \%)$, other two parties -7 seats each one $(7 \%)$. Besides, these parties are purely propresidential and progovernmental ones.

The second argument against pluralism is the complicated registration process of political parties. The requirement of 40000 members for a party to be registered by the Ministry of Justice is considered to be untenable and hardly realizable. Civil society organizations have often been suppressed throughout the history of independent Kazakhstan. They haven't been able to grow enough to form a political party and be registered as a party. In $21^{\text {st }}$ century Kazakhstani government implements new methods of repressions (as a typical informational autocracy): "Rather than jailing thousands, they target opposition activists, harassing and humiliating them, accusing them of fabricated crimes, and encouraging them to emigrate. When these autocrats kill, they seek to conceal their responsibility." $[8,100]$

The regime has been uprooting such political and civil movements from the very start of the country, in 1990's. The protests and uprisings of more than 1000 participants have been a rare phenomenon in the history of the independent Kazakhstan. Basically, the first mass protest counting to several thousand participants took place in 2016. People protested against the land reform which allowed foreign citizen to take land for long-term lease.

\section{Social media as the platform for political mobilization in Kazakhstan}

In the conditions of the absence of political pluralism and civil society, social media have become the heart of the grassroots advocacy and alternative political views. Virtual space of the internet has provided new opportunities for social and political grievances to be expressed. The online political sphere lives in the form of personal and public blogs on Youtube, Facebook, and Instagrame. Significant advantage was an increasing coverage of the internet connection. The share of the people with the internet was around 14 million people (77\%) in 2017 and 17.148 million in 2019 according to the official data by the Ministry of Information and Communication. [9]

Top seven Youtube blogs of political critics and opposition activists that I analyzed are relatively young - started between in 2015-2019. Oppositional channels BASE and the Channel 16/12 are $20^{\text {th }}$ and $31^{\text {st }}$ most popular blogs on Youtube in Kazakhstan. [14] The social media accounts discussing social and political life of the country, public policies and the corrupted political elites are increasing steadily. Thus, people's thirst to the alternative "truths" is reflected in the popularity of the Youtube accounts and Facebook pages of the critics and oppositional activists in comparison with the pages of the propresidential party.

Youtube and Instagram accounts can be compared in terms of the number of subscribers. DCK is an absolute champion on Youtube in comparison with the propresidental party of Kazakhstan and the president's press office. (See Table 1 below) Ablyazov has 138 times more subscribers on Youtube than Nur Otan and 63 times more subscribers than the president press office. On Instagram the DCK leader has more subscribers than the party Nur Otan and less than the president's press office. So, no doubt, the movement is of high interest to the general public in Kazakhstan. Considering the threat 
of official prosecution for being subscribed to the DCK and liking their posts, which cases are numerous, the registered number of people interested could be much more.

\begin{tabular}{|l|l|l|l|l|}
\hline Organization & Description & $\begin{array}{l}\text { Facebook } \\
\text { (January 2020) }\end{array}$ & Youtube (January 2020) & $\begin{array}{l}\text { Instagram } \\
\text { (January } \\
\mathbf{2 0 2 0})\end{array}$ \\
\hline $\begin{array}{l}\text { Nur Otan } \\
\text { Leader: First } \\
\text { president, N. } \\
\text { Nazarbayev }\end{array}$ & $\begin{array}{l}\text { Propresidential party, } \\
\text { elected seats in the } \\
\text { Parliament. }\end{array}$ & 16478 followers & $\begin{array}{l}2,200 \text { subscribers, } \\
\text { 590,965 views } \\
\text { (Official Youtube-channel } \\
\text { of the Party "Nur Otan", } \\
\text { joined June 2013) }\end{array}$ & $\begin{array}{l}169,000 \\
\text { subscribers, } \\
3,441 \text { posts }\end{array}$ \\
\hline $\begin{array}{l}\text { Official page } \\
\text { of Ak Orda }\end{array}$ & $\begin{array}{l}\text { The press-service of } \\
\text { the president of the } \\
\text { Republic of } \\
\text { Kazakhstan) }\end{array}$ & 42,676 followers & $\begin{array}{l}4,380 \text { subscribers, } \\
1,182,747 \text { views } \\
\text { (joined July 2012) }\end{array}$ & $\begin{array}{l}345,000 \\
\text { subscribers, } \\
1,361 \text { posts }\end{array}$ \\
\hline $\begin{array}{l}\text { Mukhtar } \\
\text { Ablyazov }\end{array}$ & $\begin{array}{l}\text { Democratic Choice } \\
\text { of Kazakhstan leader }\end{array}$ & $\begin{array}{l}\text { Private account, } \\
\text { information on } \\
\text { friends and fans is } \\
\text { closed. }\end{array}$ & $\begin{array}{l}\text { 276,000 subscribers } \\
77,372,662 \text { views } \\
\text { (joined June 2017) }\end{array}$ & $\begin{array}{l}228,000 \\
\text { subscribers, } \\
3,914 \text { posts }\end{array}$ \\
\hline $\begin{array}{l}\text { Information } \\
\text { Channel } \\
\text { "16/12" }\end{array}$ & Belong to DCK & 1020 followers & $\begin{array}{l}539,000 \text { subscribers, } \\
151,995,617 \text { views } \\
\text { (joined June 2013) }\end{array}$ & $\begin{array}{l}114,000 \\
\text { subscribers, } \\
2,841 \text { posts }\end{array}$ \\
\hline
\end{tabular}

Table 1: Comparison of social media accounts of the DCK movement, propresidential party and the president's press office account

Source: own materials

The social media management software is extremely useful in the analysis of social media impact on the political socialization processes. One of the handy tools is the statistics and analysis of the content in the SMM. The analysis of the statistics of seven most popular political Youtube bloggers-activists or oppositional channels with known authorship shows the most viewed content. (See Figure 1) It is worth noting that four out of these seven channels' authors reside outside of Kazakhstan: France, Ukraine.

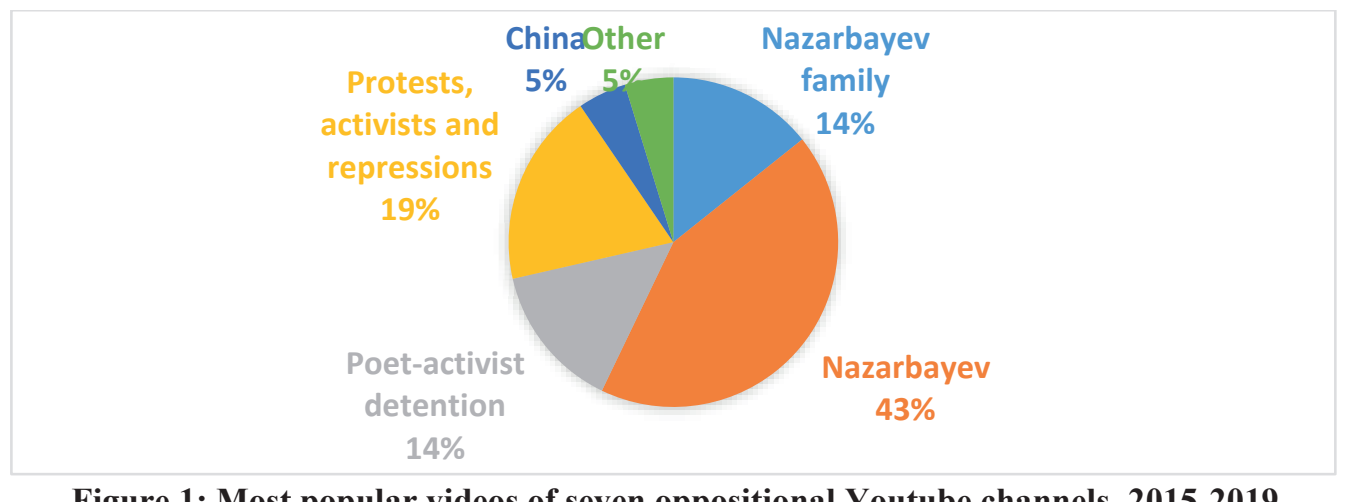

Figure 1: Most popular videos of seven oppositional Youtube channels, 2015-2019

(BASE, Channel 16/12, LIFE KZ, Yermek Narymbay, Yerzhan Turgumbay, Azamat Baikenov, Askar Shaigumarov)

Source: own materials based on data from LiveDunes

In the last five years the posts that caused most interest among their audience were dedicated to the following topics: the first president, Nazarbayev, and his family; protests and civil activists; the detention of the Kazakh poet, R.Zayitov, for participating in protests and, finally, the Chinese expansion in Kazakhstan. The Nazarbayev personality, forecasts for his future presidential tenure and 
his family members in the higher state positions constitute an absolute majority of the most viewed videos $(57 \%$, see the chart below). I suggest that people are hungry for alternative truths about the ruling elites of the country. That is why they are curious about truth revealing channels.

No doubt that the main oppositional power is concentrated in the hands of the political dissident and businessman, Mukhtar Ablyazov. In April 2017 Kazakhstani businessman M.Ablyazov founded the social movement the Democratic Choice of Kazakhstan (DCK) which he announced on his Facebook page. [1] Substantively, it was a revival because his oppositional movement started in early 2000's but was interfered with political repressions and multiple imprisonments. Lastly, in december 2016 Ablyazov was released and granted political asylum in France in 2016.

Undoubtedly, the practice of the DCK has paved the way for new political movements. Today, besdies DCK, there are four social movements/non-governmental organizations located in Kazakhstan which make political claims and inform about human rights situation: Qaharman (Hero), Oyan,Kazakhstan!, Respublika, Men Azamat (I am a citizen). These four movements appeared in 2019 as a result of the increasing number of the protests organized by the DCK and political activists. The distinctive features: they are leaderless and are organized by groups of young people, thus, represent the grassroots activity. Among officially registered NGOs only the International Bureau of Human Rights and Rule of Law in Kazakhstan works out and expresses political complaints and informs about human rights violations in the country. The civil rights and political movements have never been able to grow enough to be able to exert any influence on the government. So, the emergence of four civil movements in one year is a big step towards political socialization. That is why, I suggest that with the emergence of the first Facebook and Youtube-based oppositional social movement, Democratic Choice of Kazakhstan in 2017, the process of political socialization has started.

Protest actions statistics during the last five years, 2015-2019, in Kazakhstan is represented in the table 2 below. Using independent foreign news agencies reports, particularly Radio Freedom, Sputniknews and KazTag Agency, I collected data on the kind of protest, estimates of the participants and detainees.

In short, there are three forms of contentious actions present: strikes (mostly of oil mining, ore mining and coal mining industries), mass protests (with social and political claims and grievances) and single pickets.

My conclusion about the strong mobilizational power of social media is based on several arguments. Firstly, the oppositional movement DCK exists only in social media. Its leader does not take part in any activities in Kazakhstan because he lives in France. Secondly, for the first time in the history of almost 30 years of independence protest rallies took place in more than two cities of Kazakhstan, usually 5-cities simultaneously. So, DCK was the major organizer of the largest mass protest since independence which took place on the presidential election day, June 9-10, 2019, with over 5000 participants and around 4000 detainees. Active participants of this movement avoid admitting their involvement with the movement. In spite of this fact, since their first organized rally in May 2018, their protests are held systematically and extend to multiple cities of Kazakhstan simultaneously. The movement is well organized: since its foundation in April 2017, the leader made his program of reforms available to all those interested.

The nature of the protest actions has changed. Traditionally, civil activity was very low in the country. Only strikes of oil and mining industries were more or less common feature. Year 2011 is memorable for a series of ongoing strikes in the Western region through the whole year and the bloodiest one in 
December with around 17 workers killed. But strikes never spilled over one region. In the last two years the number of strikes and their tension decreased.

In the last two years a general social unrest became the boiling point: number of the mass protests with economic, political and social grievances as the main focus, increased, particularly in 2019. Since the start of the activity of the DCK, number of protests of more than 100 participants increased considerably. Most importantly, these rallies took place in at least five big cities of Kazakhstan.

It should be highlighted that protests and uprisings at all levels take place in spite of tightening control over freedom of expression and freedom of association: more and more activists are detained, arrested and fined; social media and internet started to experience blockages and massive shutdowns. The third outstanding feature is that all organized protests extend to multiple cities. The first organized protest movement which took place in May 2018 expanded to eight cities.

\begin{tabular}{|l|c|c|c|c|c|}
\hline Form of collective action & $\mathbf{2 0 1 5}$ & $\mathbf{2 0 1 6}$ & $\mathbf{2 0 1 7}$ & $\mathbf{2 0 1 8}$ & $\mathbf{2 0 1 9}$ \\
\hline Strikes, total: & $\mathbf{5}$ & $\mathbf{4}$ & $\mathbf{6}$ & $\mathbf{2}$ & $\mathbf{2}$ \\
\hline Strikes, $<100$ participants & 3 & 2 & 4 & 2 & 2 \\
\hline Strikes: $>100$ participants & 2 & 2 & 2 & 0 & 1 \\
\hline Protests, total: & 14 & 14 & 8 & $>13$ & $>18$ \\
\hline Protests $>1000$ participants & $\mathbf{0}$ & $\mathbf{2}$ & $\mathbf{0}$ & $\mathbf{0}$ & $\mathbf{1}$ \\
\hline Protests $(100 ; 1000)$ & $\mathbf{2}$ & $\mathbf{2}$ & $\mathbf{0}$ & $\mathbf{4}$ & $\mathbf{8}$ \\
\hline Single pickets & $\mathbf{3}$ & $\mathbf{6}$ & $\mathbf{9}$ & $\mathbf{8}$ & $>\mathbf{1 5}$ \\
\hline
\end{tabular}

Table 2: Forms of contentious collective actions present in Kazakhstan, 2015-2019

Source: own materials, data collected by the author

Besides of the quantitative characteristics of protest actions, the qualitative part deserves even more attention. The data extracted by the SMM platform LiveDune allowed me to summarize data on the Youtube posts of the leader of DCK, Ablyazov, based on the speed of receiving likes. So, three videos that caused the highest immediate interest among people were concerned with the catastrophic event, the presidential elections of 2019 and the promising reform of credit amnesty:

1. Video in the aftermath of the explosion of military ammunition dump which resulted in the evacuation of the whole city of around 100000 people (June 24, 2019, 1,138,351 views);

2. Video on the organization of mass protests in the aftermath of the presidential elections and on the day of inauguration day (June 12, 2019; 964,508 views);

3. Video on the credit amnesty promised by the president Tokayev (June 26, 2019).

The statistics of the Youtube posts of the opposition leader demonstrates that people are eager to find out the perspective of Mr. Ablyazov on the most notable events: the explosion catastrophe, unexpected political changes or social events. Also, the statistics on view counts during 2017-2019 shows that the peaks of views correspond with the mass protests periods. Each peak of views quantity can be explained by the mass protest actions taken place in this period. It means that the general public are interested in the fate of protests and protesters. 


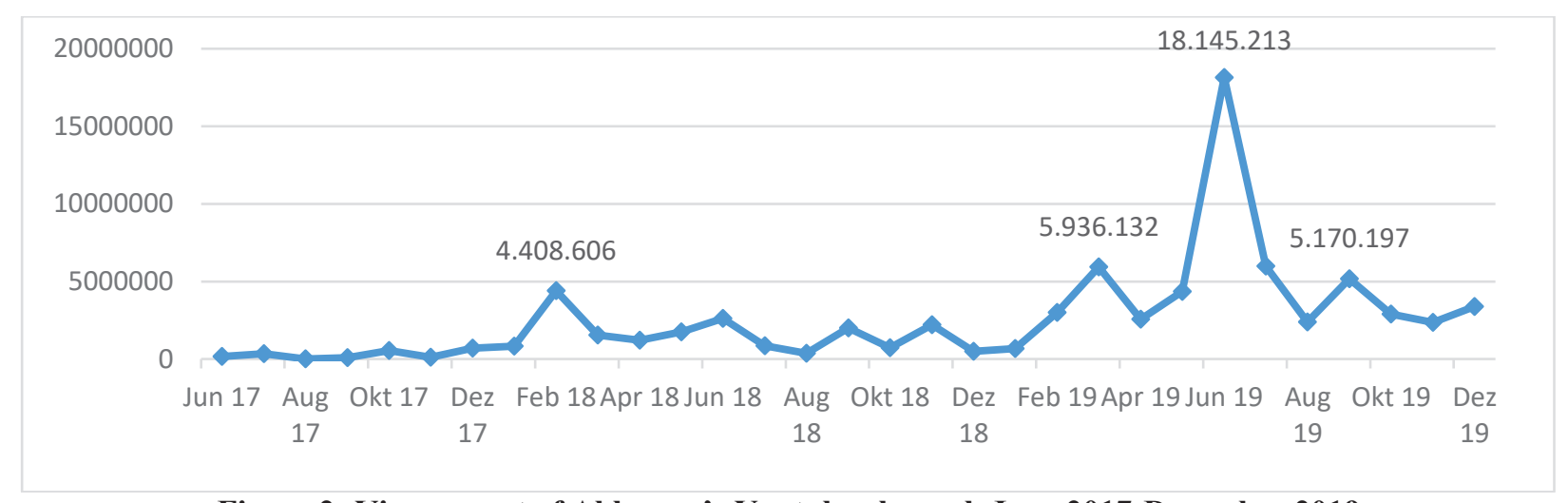

Figure 2: Views count of Ablyazov's Youtube channel, June 2017-December 2019 Source: data extracted from LiveDunes software

Text mining methods extract the substance of the protest movements organized by the DCK. Using the Microsoft Word translator for translating the leader of the DCK movement Facebook posts from Russian into English, I made corrections to the texts to reach the systematical translation of the same meaning words. Also, text data was cleaned and stemmed. So, the words in figures and tables are shown in stemmed versions.

Mr. Nazarbayev is not only intensively discussed by Ablyazov but also most extensively. The next table shows the "count" as the total number of occurrences of the term in the corpus of texts and the "support" as the number of texts containing the term. In general, all major public policy issues discussed in the opposition's posts converge to the Nazarbayev's activity and regime.

\begin{tabular}{|c|l|c|c|}
\hline No & term & count & support \\
\hline 1 & nazarbayev & 1469 & 1126 \\
\hline 2 & Countri & 1169 & 872 \\
\hline 3 & Will & 1165 & 812 \\
\hline 4 & People & 933 & 708 \\
\hline 5 & Kazakhstan & 843 & 693 \\
\hline
\end{tabular}

Table 3: Most frequent terms met in most texts in Ablyazov Facebook posts. Source: own materials.

To delve deeper into what statements are made about Nazarbayev in Ablyazov's posts I provide the following data. Firstly, R statistics show that the closest correlation with "Nazarbayev" is with the word "billion" (with correlation 0.31): in text it refers the amounts of billion dollars stolen from the budget by Nazarbayev and his elite.

Secondly, I extracted two, three and five words that most frequently go together: half of the most frequents pairs are something about Nazarbayev, the rest are human rights, democratic choice, supporters of DCK, etc. (See Table 4 below)

\begin{tabular}{|l|l|l|l|l|l|}
\hline term & count & support & term & count & support \\
\hline Nazarbayev regime & 126 & 124 & Democratic choice & 51 & 51 \\
\hline Human right & 121 & 97 & Whole countri & 49 & 47 \\
\hline Nursultan Nazarbayev & 56 & 54 & Support DCK & 51 & 46 \\
\hline People Kazakhstan & 56 & 54 & Nazarbayev will & 49 & 46 \\
\hline Old man & 52 & 52 & Nazarbayev famili & 47 & 46 \\
\hline
\end{tabular}

Table 4: Most frequent two-word terms met in most texts in Ablyazov Facebook posts. Source: own materials. 
The data of the most frequent mentions accompanying 'Nazarbayev' term shows the following: 'Nazarbayev regime', 'Nazarbayev family', 'Nazarbayev said', 'Nazarbayev plans', 'Nazarbayev entourage'. Not a single word includes a violent emotion or call for criminal action towards this person. He is discussed in terms of his deeds during the presidency, his supposedly multi-billion wealth, his plans for the future and the entourage related to the personality cult.

Text cluster analysis provides most wholesome picture of the social movement DCK. Using agglomerative hierarchical clustering with Ward's method as the merge rule, based on the dendrogram I clustered the Facebook posts of Ablyazov into 11 clusters. The cluster analysis confirms that the main subject of the opposition's posts is Mr. Nazarbayev: three clusters are related to the first president and his family, his personalist ruling and venalities, the personal enrichment. (Clusters 2, $4,9)$ Two clusters are devoted to the activity and tactics of the DCK: how to increase the numbers of supporters of the DCK, how to join ranks of the DCK and how to defend human rights, particularly, of the activists. (Clusters 5,11) The first is the largest cluster which covers all public policy issues, the current president Tokayev, politics towards political prisoners and protesters, Kazakhstan's relationships with China and Russia.

Cluster analysis reveals another important aspect of the DCK movement leader activity, that is informational and analytical and his attempts to deliver his perspectives on the current public policy issues that Kazakhstan has been facing.

\begin{tabular}{|c|c|l|}
\hline N & $\begin{array}{c}\text { Cluster } \\
\text { size }\end{array}$ & Top words \\
\hline 1. & 4570 & kazakhstan, protest, prison, day, tokayev, action, astana, kazakh, china, russia \\
\hline 2. & 139 & bank, teng, billion, dollar, nazarbayev, budget, month, million, averag, salari \\
\hline 3. & 391 & $\begin{array}{l}\text { orevoir, vpn, diakovski, vyacheslav, jezcazgan, casin, esimov, samruk, gennadigon, } \\
\text { hralyam }\end{array}$ \\
\hline 4. & 41 & old, man, gone, youth, new, elixir, away, quot, invent, sign \\
\hline 5. & 206 & dck, support, party, activist, rank, join, peopl, leaflet, cell, member \\
\hline 6. & 125 & $\begin{array}{l}\text { elect, presid, kosanov, candid, parliamentari, power, presidenti, parliament, vote, } \\
\text { fair }\end{array}$ \\
\hline 7. & 61 & right, human, kazakhstani, know, defend, freedom, law, court, countri, world \\
\hline 8. & 47 & million, oil, dubai, produc, ton, total, region, emir, atyrau, per \\
\hline 9. & 23 & nazarbayeva, dariga, hanstv, man, billion, presid, horr, kulyakh, atom \\
\hline 10. & 45 & chang, will, need, survey, realiz, power, push, respond, abl, system \\
\hline 11. & 24 & free, kazakhstan, will, protest, dck, eugen, man, kravet, schoolchildren, evgeni \\
\hline
\end{tabular}

Table 5: Cluster analysis results.

Source: own materials.

The tactics of the Democratic Choice of Kazakhstan encompasses peaceful protest rallies, information dissemination and attracting more supporters. The main goal of the movement is to change current political regime of Nazarbayev. The closest correlation with the "DCK" is "support/supporters" term (correlation 0.41): Ablyazov insists on increasing numbers of supporters. He believes that the only way to change the current political regime is by attracting more supporters of the DCK and organize protests of several thousands of people so that police were unable to intimidate and repress activists. Power is in numbers. Non-violent nature of the protests organized by the DCK is supported by the 
argument that "protest" comes only with adjectives peaceful, lite and mass ("peace" and "lite")2. No harsh language is introduced in the oppositional posts. It should be noted that the court's decision was made in March 2018 on the basis of the social media accounts of the movement DCK, thus, before the massive protest rallies of 2019. The largest protest rally took place in June 2019 during the presidential elections: more than 4000 detainees were reported. At the same time news channels reported no damages towards private property. However, three policemen were reported to have minor injuries in the capital city. However, no reports on the injured civilians were made. In general, by now the political activism in Kazakhstan is surely far from either violent or destructive. One of the possible reasons is the fear of the ordinary citizens of the overwhelming power of authorities and their competences to use force. Obviously, harsh critique and calls for change of the current political regime could not have gone unnoticed by the dictatorial authorities.

\section{Conclusion}

The analysis of social media accounts of the social movement leader produces indirect evidence of the real current political, economic and social situation. Not only content touched upon by the political activists, but also the reaction of social media users and viewers demonstrate the topical issues in the country. Social media is extremely important alternative channel of information in modern authoritarian countries.

First, I situated Kazakhstan as being a representative of the sultanistic regime in Linz (2000), personalist authoritarian in Geddes (1999) and informational autocracy in Guriev and Treisman (2019). The role of specific individuals is highly important on Kazakhstan's online political sphere. There are a lot of personal accounts and informational channels on Youtube with political content and political claims and critique. While the government does not have necessary technologies to censure and control the internet social networks directly, it is authorized to it legally. That is why many activists and bloggers are targeted and jailed as it does happen in the informational autocracies. Several popular political bloggers are located outside of Kazakhstan. They are the ones who produce the harshest critique and call for mass protests setting the dates for ordinary people.

The cluster analysis and data mining techniques confirm that the DCK leader's account is focused on revealing information, alternative truths, about the activities of the long-lasting president and his ruling elites to the masses. The analysis of the Youtube channels of political activists confirms that the audience is most interested in the topic "Nazarbayev and his family". These facts add to the argument for the autocratic personalist rulership of the country.

The main message of the social media-based movement leader is that the standard political participation intrinsic to democratic nations is not viable in the current political regime because of rigged elections and widespread corruption. That is why he concludes that the parliamentary form of government with the complete removal of the position of president should replace the current regime. This can only be realized through the "lite protests" (no weapons) with several thousand participants. No doubt, there is no violence towards the first president mentioned.

\footnotetext{
${ }^{2}$ List of terms with "protest": "go protest", "protest protest", "mass protest", "peac protest", "hold protest", "liber protest”, "come protest", "organ protest", "held protest", "lite protest".
} 


\section{References}

[1] ABLYAZOV, M., 2017. "Announcement on the establishment of the civil movement 'Democratic Choice of Kazakhstan.'” Facebook. April 20, 2017. https://www.facebook.com/ mukhtar.ablyazov

[2] CASTELLS, M., 2015. Networks of Outrage and Hope: Social Movements in the Internet Age. 2 edition. Cambridge, UK ; Malden, MA: Polity.

[3] CHEHABI, H. E. and LINZ, J. J., eds. 1998. Sultanistic Regimes. 1St Edition edition. Baltimore: Johns Hopkins University Press.

[4] "Democracy Has Grown across the World over the Past Four Decades." 2019. Pew Research Center. March 13, 2019. https://www.pewresearch.org/fact-tank/2019/05/14/more-than-halfof-countries-are-democratic/ft_19-05-02_democracyupdate_map/.

[5] DIAMOND, L., 2015. "Facing Up to the Democratic Recession." Journal of Democracy 26 (1): 141-55. https://doi.org/10.1353/jod.2015.0009.

[6] "Freedom in the World 2019. Country Report. Kazakhstan." 2019. January 30, 2019. https://freedomhouse.org/report/freedom-world/2019/kazakhstan.

[7] GEDDES, B., 1999. "What Do We Know About Democratization After Twenty Years?" Annual Review of Political Science 2 (1): 115-44. https://doi.org/10.1146/annurev.polisci. 2.1.115.

[8] GURIEV, S. and TREISMAN, D., 2019. "Informational Autocrats." Journal of Economic Perspectives 33 (4): 100-127. https://doi.org/10.1257/jep.33.4.100.

[9] KOVAlEVA, T., 2018. "Abayev: about 77\% of Kazakhstan is with the internet." Zakon.kz. February 16, 2018. https:/www.zakon.kz/4904189-abaev-77-naseleniya-kazahstana.html.

[10] LINZ, J. J. and STEPAN, A., 1996. Problems of Democratic Transition and Consolidation: Southern Europe, South America, and Post-Communist Europe. Baltimore: Johns Hopkins University Press.

[11] LINZ, J. J., 2000. Totalitarian and Authoritarian Regimes. Lynne Rienner Publishers.

[12] MCKEON, R.T., GITOMER, D. H., 2019. "Social Media, Political Mobilization, and HighStakes Testing." Frontiers in Education 4. https://doi.org/10.3389/ feduc.2019.00055.

[13] MOROZOV, E., 2012. The Net Delusion: The Dark Side of Internet Freedom. Reprint edition. New York, NY: PublicAffairs. Morozov, Evgeny. 2012. The Net Delusion: The Dark Side of Internet Freedom. Reprint edition. New York, NY: PublicAffairs.

[14] "Rating and statistics of Youtube in Kazakhstan." n.d. LiveDune. Accessed January 25, 2020. https://livedune.ru/youtube/country/kazakhstan. 
[15] "Social Media Stats Kazakhstan." n.d. StatCounter Global Stats. Accessed April 4, 2020. https://gs.statcounter.com/social-media-stats/all/kazakhstan.

[16] TILLY, C., 1978. From Mobilization to Revolution. Reading, Mass: Addison-Wesley.

[17] TUFEKCI, Z. and WILSON, C., 2012. "Social Media and the Decision to Participate in Political Protest: Observations from Tahrir Square." Journal of Communication 62 (2): 36379. https://doi.org/10.1111/j.1460-2466.2012.01629.x. 